\title{
Arent van Bolten y la comicidad de lo grotesco. A propósito de los dibujos que integran la revista Ciencias Sociales y Educación n.0 19*
}

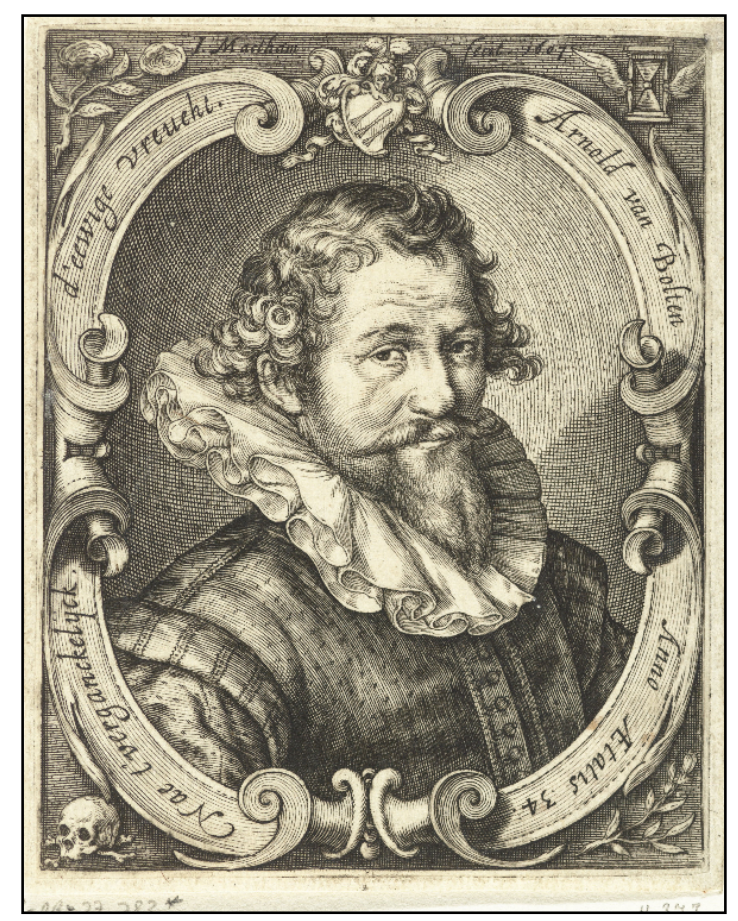

Retrato de Arent van Bolten de Jacob Matham

Fuente: Museo Nacional de Ámsterdam (1607).

Hilderman Cardona-Rodas

Facultad de Ciencias Sociales y Humanas Universidad de Medellín, Medellín, Colombia hcardona@udem.edu.co

https://orcid.org/0000-0002-6778-2102

Cómo citar: Cardona-Rodas, H. (2021). Arent van Bolten y la comicidad de lo grotesco. A propósito de los dibujos que integran la revista Ciencias Sociales y Educación no. 19. Ciencias Sociales y Educación, 10(19), 405-410. https://doi.org/10.22395/csye.v10n19a16

Recibido: 24 de marzo de 2021.

Aprobado: 8 de abril de 2021. 


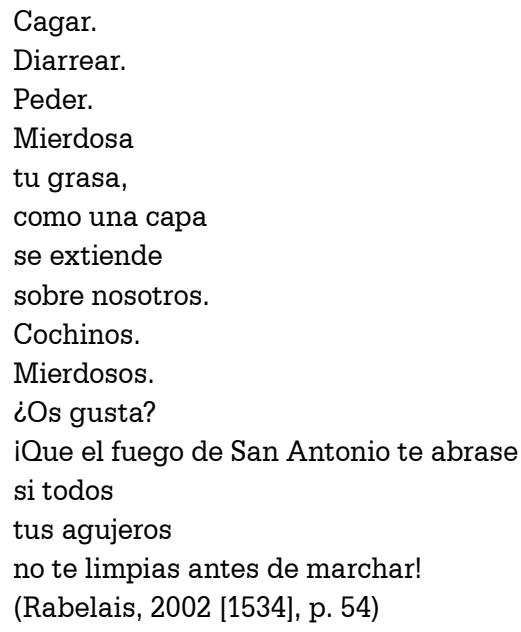

François Rabelais (1494-1553), médico, escritor y humanista francés, publicó en 1534 una obra fundamental sobre la cultura de la risa que proyecta una imagen de lo grotesco de la condición corporal humana: Gargantúa y Pantagruel. En el capítulo XIII del libro primero narra la historia de la invención de un limpiaculos. Grandgousier visita a su hijo Gargantúa y comienzan a conversar sobre la limpieza corporal, este último le dice a su padre que ha inventado "un medio de limpiarme el culo". Esta es la descripción que el hijo le da a su padre sobre el invento:

Una vez me limpié con un antifaz de terciopelo, de una señorita, y lo encontré bueno, porque la molicie de la seda me causaba en el fundamento una voluptuosidad muy grande. Otra vez con un sombrero de señora y me ocurrió lo mismo; otra vez con una pañoleta; otra con unas orejas de satén carmesí; pero unos bordados con abalorios de mierda que tenía, con su dureza, me desollaron el trasero; ique el fuego de San Antonio ${ }^{1}$ encienda la morcilla cular del orfebre que los hizo y de la señorita que los llevó! El mal se me curó frotándome con un bonete de paje bien emplumado a la suiza. (Rabelais, 2002 [1534], p. 53)

Gargantúa recuerda que también utilizó los bojes de un cachorro de marta, con tal suerte que con sus uñas le laceró el periné; para curarse recurrió a los guantes de su madre bien perfumados de benjuí. Se limpió también con sauce, mejorana, rosas, hojas de col, trozos de ladrillo, además de hierba mercurial, persicaria, ortigas, consuelda, que le ocasionaron un flujo de sangre. Pero lo curó al limpiarse con su bragueta, las sábanas, la colcha, las cortinas, un cojín, un lápiz..., con una servilleta, con un peinador. "Con todo esto sentí tanto placer

El fuego de San Antonio era una erupción herpética, endémica en la época de Rabelais, que se presentaba en la parte inferior de las piernas. La cultura popular de aquel entonces la atribuía a un castigo enviado por ese santo. 
como sienten los que sufren de roña cuando se les rasca" (Rabelais, 2002 [1534], p. 54). Finalmente, recita Gargantúa:

\author{
Rodó \\ Al cagar olí antesdeayer \\ el tributo que mi culo pagaba; \\ y el olor me hizo temer \\ que allí mismo me asfixiaba. \\ iQuién me hubiera podido traer \\ una mujer que yo esperaba \\ cagando! \\ iQué bien le hubiera sazonado \\ su mingitorio a mi manera lerda, \\ si ella me hubiese ayudado \\ con sus dedos a desalojar mi mierda \\ cagando. (Rabelais, 2002 [1534], pp. 54-54)
}

Para Gargantúa solo se ha de tener el culo sucio para limpiarlo, y el mejor limpiaculos es un pollo de oca con sus plumas; lo coge de la cabeza entre las piernas, aprovecha la dulzura del plumón y el calor del animal, y permite la comunicación con la "morcilla cular" y los otros intestinos, hasta llegar, dice, a las regiones del corazón y el cerebro.

Como se aprecia en los fragmentos seleccionados de la novela de Rebelais, el humor carnavalesco es ante todo un humor festivo, gozoso y corporal. La hilaridad se hace visible en la revelación de lo que causa estupor por su evidencia natural en la comicidad de la cultura popular. La presencia vergonzante del ano y sus ventoseos da lugar a lo repugnante en la risa, que se manifiesta por su certeza en la condición corporal de la existencia humana. El aspecto jocoso de lo que narra el escritor francés pone en juego una ambivalencia por el hecho ser alegre y al mismo tiempo burlón y sarcástico, que niega y afirma al unísono. En la narrativa de Rabelais,

A diferencia de la fiesta oficial, el carnaval era el triunfo de una especie de liberación, más allá de la órbita de una concepción dominante, la abolición provisional de las relaciones jerárquicas, privilegios, reglas y tabúes. Se oponía a toda perpetuación, a todo perfeccionamiento y reglamentación, apuntaba a un porvenir aún incompleto. (Bajtin, 2003, p. 13)

En los modos discursivos del carnaval el ser humano vuelve a sí mismo y se integra con sus semejantes. Con ello, cuestiona las relaciones jerárquicas sociales, en donde el auténtico humanismo, enseñanza de Rabelais, no se halla en un pensamiento abstracto, sino que se experimenta como algo vivo, material y sensible. La comicidad fecal (Werner, 2013) genera risa en toda persona ante la cercanía de sus excrementos, que desestabilizan su identidad al mostrar dolorosamente la vanidad y finitud de toda existencia humana. He aquí el 
vínculo entre ano y boca en el modo de producción deseante de aquello que se rechaza en la función simbólica del arriba y del abajo.

En los dibujos de Arent van Bolten (1573-1633), quien fue retratado por el grabador y dibujante holandés Jacob Matham en 1607, la nariz de sus animales fantásticos está al nivel del ano. Sus obras muestran la experiencia estética de lo grotesco ${ }^{2}$, en cuanto imágenes del cuerpo y la vida corporal en su paroxismo cómico. Aquí el cuerpo grotesco representado pone el acento en grietas y pliegues, a partir de las cuales el mundo se introduce en la fábula visual representada. Además, exhala humores y sonidos paradójicos que le dan fuerza a una idea del cuerpo que se debate en una dialéctica en reposo (Benjamin, 2010) y que se agita al conmover el carácter rígido de la mirada en el dinamismo de la imaginación de lo imposible en lo posible.

Cada vez que nos hallamos ante una imagen nos encontramos ante tiempos heterogéneos que se despliegan en un anacronismo transmisor de fulguraciones, aleteos, en el juego de las temporalidades que no se restringen a una mera cronología taxativa de inscripción de la imagen a un contexto cerrado y restrictivo, rompiendo con ello las barreras de la historia. La inmanencia de la imagen es el desplazamiento y el dinamismo al romper con cualquier límite temporal; por ello la imagen evoca la vida de una mariposa por su belleza, variedad de formas, por sus colores y su fragilidad en metamorfosis y mimetismo. He aquí el aleteo, el parpadeo o el fogonazo o relámpago que evocará Walter Benjamin cuando hable de las imágenes en su efervescencia corporal. Cuando la imagen se deja ver, las intermitencias del aleteo de una mariposa sorprenden en un zigzag de lo que puede un cuerpo en la expresividad del movimiento. (Cardona-Rodas, 2017, pp. 120-121)

La imagen en su efervescencia corporal encuentra en las obras que se seleccionaron para el número 19 de la revista Ciencias Sociales y Educación la intermitencia en lo liminal de lo fantástico. Por ello, la imagen de lo grotesco adquiere todo su sentido icónico en el encuentro con los límites del mundo que conocemos, recordando nuestros propios límites y nuestra propia mortalidad. "Como un minotauro, una sirena o un ciborg, lo grotesco no es ni una cosa ni otra, y esta criatura límite vaga por las fronteras de todo lo que es familiar y convencional" (Connelly, 2015, p. 23). Lo grotesco hace referencia a artificios fantasiosos llenos de virtuosismo e imaginación. En este sentido, la exageración (hiperbolización) es, como recuerda Bajtin, uno de sus signos característicos que manifiestan la vida grotesca del cuerpo. Estos fenómenos corporales, representados en las imágenes de Bolten y en la narrativa de Rabelais, ponen de

2 Grotesco, gruttesco, se deriva del sustantivo italiano grotta, es decir, gruta. "En el último cuarto de la década de 1400, se excavaron en Roma las ruinas del Palacio de Nerón, la Domus Aurea, revelando decoraciones murales con combinaciones caprichosas de plantas, figuras, criaturas míticas y elementos arquitectónicos. Como las habitaciones estaban por debajo del nivel del suelo, como en una gruta, las invenciones fantásticas y bizarras allí encontradas empezaron a ser conocidas como grottesche" (Connelly, 2015, p. 26). 
manifiesto pequeños dramas satíricos de la palabra y la imagen, "el drama de su nacimiento material, o el del cuerpo que da origen a la palabra" (Bajtin, 2003, p. 255). Este drama, en términos de una dialéctica en reposo, despliega la esfera material y corporal: comer, cagar, ventosear, beber, cantar, dormir, combatir, conversar, desear, vida sexual... el mundo de los hechos corporales parodiados. Imágenes y palabras mezclan el mundo y el cuerpo en hipérboles simbólicas de proporciones inverosímiles.

Es necesario resaltar que lo grotesco despliega dos ideas fundamentales: la primera tiene que ver con su efecto perfomativo y provocador; y en la segunda, lo grotesco juega con las cosas disponibles como un artificio de lo posible. "Como imágenes visuales, las imágenes grotescas fluyen: pueden ser aberrantes, combinatorias y metafóricas. Este fluido visual es necesario, pero no suficiente en sí mismo para definir lo grotesco porque, en su fuero interno, lo grotesco es algo generado culturalmente" (Connelly, 2015, p. 23). De esta forma, lo grotesco se revela a través de sus momentos intersticiales en los que lo familiar adquiere la expresión de lo extraño y hace variar en un torbellino interpretativo la figura polimorfa del cuerpo en su comicidad. Esperamos que el lector de este número de la revista se deleite ante el acto de provocación estética que proyectan los dibujos de Arent van Bolten en la comicidad de lo grotesco.
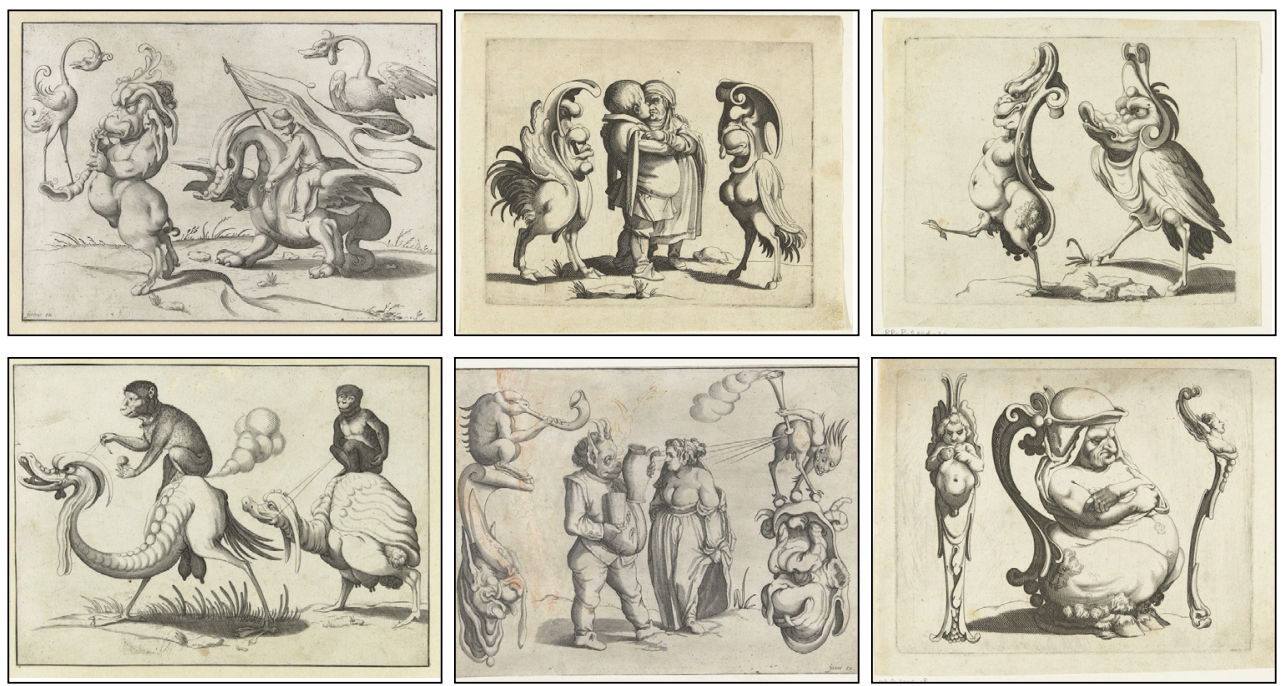

Selección de imágenes que integran este número de la revista n. 19

Fuente: Museo Nacional de Ámsterdam (1596-1602). 


\section{Referencias}

Bolten, A. (1596-1602). Dibujos grotescos [dibujos] Museo Nacional de Ámsterdam, Ámsterdam, Países Bajos. https://publicdomainreview.org/collection/arent-van-bolten-s-grotesques

Bajtin, M. (2003). La cultura popular en la Edad Media y en el Renacimiento. Alianza Editorial.

Benjamin, W. (2010). Ensayos escogidos. Cuenco de Plata.

Cardona-Rodas, H. (2017). Testimonios visuales de la violencia: el cuerpo desecho. En J. L. Ramírez Torres, y H. Cardona-Rodas (comps.), Narrativas corporales de la violencia y estéticas del dolor (pp. 105-132). Universidad de Medellín; La Cifra Editorial.

Connelly, F. S. (2015). Lo grotesco en el arte y la cultura occidental. La imagen en juego. La balsa de la Medusa.

Matham, J. (1607). Retrato de Arent van Bolten [grabado]. Museo Nacional de Ámsterdam, Ámsterdam, Países Bajos. https://www.rijksmuseum.nl/en/search/objects?q=Arent+van+Bolten\&s=objectt ype\&p=2\&ps=12\&st=Objects\&ii=2\#/RP-P-OB-27.283X,14

Rabelais, F. (2002). Gargantúa y Pantaguel. Panamericana Editores.

Werner, F. (2013). La materia oscura. Historia cultural de la mierda. Tusquets Editores. 